\title{
Morphological, growth and meadow characteristics of the seagrass Posidonia sinuosa along a depth- related gradient of light availability
}

\author{
Catherine J. Collier ${ }^{1, *}$, Paul S. Lavery ${ }^{1}$, Raymond J. Masini ${ }^{2}$, Peter J. Ralph ${ }^{3}$ \\ ${ }^{1}$ School of Natural Sciences, Edith Cowan University, 100 Joondalup Drive, Joondalup, Perth, Western Australia 6027, \\ Australia \\ ${ }^{2}$ Department of Environment, Westralia Square, Level 8, 141 St George's Terrace, Perth, Western Australia 6000, Australia \\ ${ }^{3}$ Institute for Water and Environmental Resource Management, University of Technology, Sydney, PO Box 123 Broadway, \\ New South Wales 2007, Australia
}

\begin{abstract}
Morphological and growth characteristics of the meadow-forming seagrass Posidonia sinuosa (Cambridge et Kuo), were measured along a depth-related gradient of light to infer its response to long-term differences in light availability. Morphometric measurements were carried out at 6 depths between 1.6 and $9.0 \mathrm{~m}$ in summer and winter at Cockburn Sound and summer only at Warnbro Sound in south-western Australia. The minimum light requirement for P. sinuosa of $8.5 \%$ sub-surface light was among the lower range reported for seagrasses. Its slow growth rate (0.5-1.5 $\mathrm{mg}_{\text {dry }}$ shoot $^{-1} \mathrm{~d}^{-1}$ ), relative to similarly sized species, may contribute to the low light requirements of this species. Shoot density, leaf area index and biomass showed pronounced and consistent differences among depths (up to 88-fold reduction of above-ground biomass from shallow to deep sites). At the deeper sites, the reduced shoot density probably reduces respiratory demand and alleviates self-shading. Morphological differences (leaf length, width and thickness and number of leaves per shoot) did not follow a clear and consistent trend with depth. Despite a $70 \%$ reduction in light availability at the canopy level between the shallowest and deepest sites, leaf growth rate was unaffected by depth during summer, and in winter differed between only a few depths. We propose that the reduction in shoot density partially alleviates the effects of self-shading and permits comparable leaf growth rates across the depth range. These results suggest that for interpreting long-term responses to light availability, shoot density is the most sensitive of the morphological characteristics measured here.
\end{abstract}

KEY WORDS: Light reduction · Posidonia sinuosa · Depth gradient · Morphology · Growth · Western Australia · Self-shading

Resale or republication not permitted without written consent of the publisher

\section{INTRODUCTION}

The depth range of a seagrass meadow may span a steep light gradient where the deeper boundary of the meadow is usually limited by the availability of sufficient light to maintain a positive carbon balance (Dennison 1987). Depth limits of seagrasses can be highly variable depending upon local environmental conditions and the seagrass species. Seagrasses colonising estuarine habitats, such as Zostera spp., commonly have a depth range of less than 2 m (Duarte 1991, Dennison et al. 1993, Abal \& Dennison 1996), while in clear Mediterranean waters, Posidonia oceanica frequently occurs at depths below 40 m (Duarte 1991). This range of colonisation depths correlates closely with the local light attenuation coefficients (Duarte 1991, Kenworthy \& Fonesca 1996), and generally corresponds to a minimum light requirement in the range of 4 to $29 \%$ of sub-surface irradiance (Dennison et al. 1993). 
Posidonia sinuosa is a strictly sub-tidal meadowforming species that is widely distributed throughout southern Australia, locally colonising depths of approximately 2 to $10 \mathrm{~m}$ in continuous and dense meadows (Kirkman \& Kuo 1990). Rhizome elongation and shoot recruitment rates in Posidonia species, particularly $P$. sinuosa, are considerably slower than for other seagrass taxa (Marbà \& Walker 1999). As a result, they are unable to migrate along the depth gradient in response to short-term fluctuations in light availability in the way that other species, such as Zostera muelleri, have been observed to do (Counihan et al. 2002). While changes to seagrass depth limits are useful for monitoring some species (Dennison et al. 1993, Abal \& Dennison 1996, Kenworthy \& Fonesca 1996), the depth limits of Posidonia species are less variable (Lavery \& Westera 2005). This means that for $P$. sinuosa to persist annually, characteristics that allow it to persist at its depth limit (rather than the rapid recolonisation that is characteristic of some other species) are crucial to its survival.

Seagrasses are sensitive to light availability across a range of scales, including individual leaf responses, shoot-scale responses and alterations to the meadow structure (Olesen et al. 2002). Morphological plasticity at the shoot-scale is a fundamental process that can maximise exposure of the photosynthetic apparatus to light, while minimising respiratory demands. Such morphological adjustments enable the meadow to persist at lower light levels, up to a threshold. Among the morphological features of seagrasses known to respond to light availability are canopy height (Bulthius 1983, West 1990, Hillman et al. 1995), leaf width (Lee \& Dunton 1997) and leaf density (Ruiz \& Romero 2001).

Data describing a number of these morphological characteristics are frequently collected during environmental monitoring programs (Lavery \& Westera 2005). An understanding of the degree to which longterm light availability affects these morphological characteristics can inform the interpretation of spatially-collected information. In the absence of direct measurement, observed differences can only be interpreted according to generalised models of seagrass light responses; however, these may not be directly transferable between species (Czerny \& Dunton 1995). The consistency with which different species adjust physiologically and morphologically to light gradients has been recently questioned (Olesen et al. 2002). In addition, there may be difficulty disentangling the influence of other spatially-variable environmental factors on these characteristics (Longstaff 2000).

Alterations to the meadow structure, expressed as changes in shoot density and biomass, have been considered symptoms of long-term light reduction (Longstaff \& Dennison 1999). Reduced leaf growth is often observed in response to light deprivation (Bay 1984, Lee \& Dunton 1997, Longstaff \& Dennison 1999, Ruiz \& Romero 2001) when the plant's carbon budget becomes imbalanced due to reduced photosynthetic carbon fixation and often requiring a draw-down on carbon reserves (Ruiz \& Romero 2001). Physiological characteristics also show some responses to reduced light, such as increased chlorophyll concentration, providing a mechanism to enhance light capture and conversion to chemical energy (Dennison \& Alberte 1985, Abal et al. 1994, Peralta et al. 2002, Ralph \& Gademann 2005). Eventually, however, morphological changes and shoot loss result (Longstaff \& Dennison 1999) and further enable persistence during long-term light reductions due to the benefits to the plant in terms of reduced respiratory demand and reduced self-shading (Olesen et al. 2002). Areas with steep gradients in light availability offer the opportunity to measure, in situ, the adaptability of seagrass to long-term light reduction with minimal influence from potentially confounding site-related factors.

The aim of this study was to characterise the meadow-scale, morphological and growth characteristics of Posidonia sinuosa along a depth-related gradient of light availability with particular emphasis on characteristics that are frequently identified as responsive to light in order to identify the characteristics that enable its persistence at depth. A further aim of this study was to identify which of these may form indicators of long-term light reduction.

\section{MATERIALS AND METHODS}

Study site. The study was conducted at Cockburn Sound (CS) and Warnbro Sound (WS) near Fremantle, Western Australia. Two locations were used to verify whether the trends in the measured Posidonia sinuosa characteristics across depths were consistent between different locations. At these locations, mostly monospecific stands of $P$. sinuosa grow on steep sub-tidal depth gradients ranging from 1 to $9 \mathrm{~m}$ depth. The CS sites were located north-east of Garden Island (Fig. 1). Sampling was carried out at 6 depths; 1.6, 4.0, 5.7, 6.5, 8.3 and $9.0 \mathrm{~m}$ (lowest astronomical tide), which will be referred to as Sites CS1, CS2, CS3, CS4, CS5 and CS6, respectively. Sampling effort was concentrated nearer to the depth limit where the greatest differences between depths were expected as light reaches levels that are limiting to the long-term maintenance of the meadow. The 5 deepest sites were located within close proximity to each other on a steep slope leading to a basin $\left(32^{\circ} 09^{\prime} 37.0^{\prime \prime} \mathrm{S}, 115^{\circ} 40^{\prime} 47.3^{\prime \prime} \mathrm{E}\right)$, while the shallowest site was located closer to the island shore approximately $800 \mathrm{~m}$ away $\left(32^{\circ} 09^{\prime} 35.6^{\prime \prime} \mathrm{S}\right.$, 


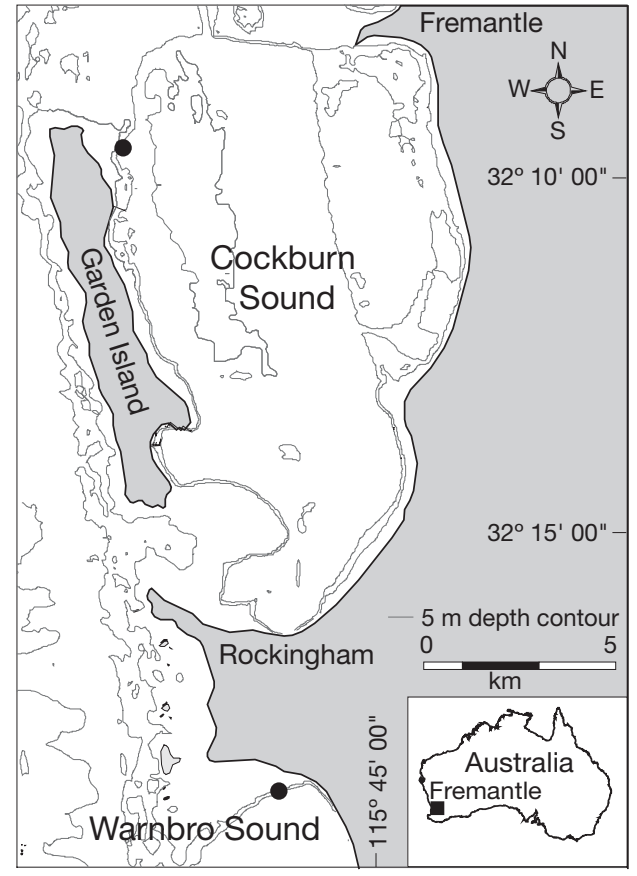

Fig. 1. Sampling locations in (•) Cockburn Sound (CS) and Warnbro Sound (WS), located south of Fremantle in southwestern Australia

$\left.115^{\circ} 40^{\prime} 16.4^{\prime \prime} \mathrm{E}\right)$. WS was sampled in the north-east of the Sound (Fig. 1) at the same 6 depths as CS, and will be referred to as Sites WS1, WS2, WS3, WS4, WS5 and WS6. Again, the 5 deepest sites were located within close proximity $\left(32^{\circ} 18^{\prime} 57.4^{\prime \prime} \mathrm{S}, 115^{\circ} 42^{\prime} 51.5^{\prime \prime} \mathrm{E}\right)$, while the shallowest site was located approximately $150 \mathrm{~m}$ away, closer to the mainland shore $\left(32^{\circ} 18^{\prime} 53.7^{\prime \prime} \mathrm{S}\right.$, $\left.115^{\circ} 42^{\prime} 50.3^{\prime \prime} \mathrm{E}\right)$.

Sampling and analysis. At CS, sampling occurred in winter (June) 2002 and in summer (January-February) 2003 with follow-up sampling on both occasions. WS was sampled in summer (January-February) 2003 only. The sites were sampled for environmental and morphological parameters and leaf growth.

Environmental parameters: Photosynthetic photon flux density (PPFD) was recorded every 15 min using submersible $2 \pi$ loggers (Submersible Odyssey Photosynthetic Irradiance Recording System, Dataflow Systems) deployed just above canopy height at $4.0 \mathrm{~m}$ and $9.0 \mathrm{~m}$ depth from September 2002 to September 2003. Surface PPFD was also recorded at the Point Peron education facility, near Rockingham (Fig. 1). The loggers were calibrated using a LI-192SA underwater quantum sensor (LI-COR) and then corrected for immersion effect using a factor of 1.33 (Kirk 1994). Automated sensor cleaners wiped the sensor free from fouling materials every $30 \mathrm{~min}$ (Carruthers et al. 2001). Continued technical difficulties prevented the collec- tion of complete annual data at WS, so extinction coefficients for a part of the summer (December 2002) and winter periods (July 2003) are given. At CS, small gaps in data were interpolated by taking the means of data blocks from a $2 \mathrm{wk}$ period on either side of the missing data. Monthly extinction coefficients $\left(\mathrm{k} \mathrm{m}^{-1}\right)$ at both locations and daily PPFD availability at each depth at CS were calculated using the Bougert-Lambert law:

$$
k=\frac{\operatorname{Ln}\left(I_{z 1} / I_{z 2}\right)}{z}
$$

where $I_{\mathrm{z} 1}$ and $I_{\mathrm{z} 2}=$ irradiance at depths 1 and $2 ; z=$ the difference between depths 1 and 2 .

Daily PPFD availability at CS6 was expressed as a percentage of sub-surface light availability. Surface light data were converted to sub-surface values by correcting for reflectance and effects of wind speed on reflectance using an average reduction of $2.5 \%$ (Kirk 1994).

Electrochemical oxidation-reduction (redox) potential of the seagrass sediments was measured at CS1, CS3 and CS6 in May 2003 to determine if there was an effect of depth-related light reduction on sediment redox potential. A stainless steel corer $(5 \mathrm{~cm}$ diameter) with tape-sealed holes located every $5 \mathrm{~cm}$ along its length was pushed into the sediment to a depth of 20 to $25 \mathrm{~cm}$. The cores were extracted, plugged at both ends and taken to the surface. A platinum electrode (WTW SenTix ORP) was inserted immediately below the surface of the sediment $(0.5-1 \mathrm{~cm}$ depth) and at $5 \mathrm{~cm}$ intervals down the length of the core after removal of the tape, and redox potential was recorded in $\mathrm{mV}$. Replicate cores (5) were taken from each site.

Biomass and morphological parameters: Biomass sampling was carried out using up to 12 replicate quadrats $(25 \times 25 \mathrm{~cm})$ in a stratified design. Percent cover of seagrass was estimated visually within a $10 \mathrm{~m}^{2}$ area at each depth. Where percent cover was less than $100 \%$, the number of replicates was reduced to the corresponding proportion of 12 samples, with the remaining samples given a zero value. All leaf and sheath material was collected from within each replicate quadrat and placed directly into a plastic bag. These were later rinsed and sorted to retain only the above-ground material. Leaves were scraped free of epiphytes and, together with the leaf sheaths, were dried at $60^{\circ} \mathrm{C}$ for $48 \mathrm{~h}$ and weighed. The number of shoots in the sample was counted to determine shoot density.

Below-ground biomass was collected in summer only to a depth of $30 \mathrm{~cm}$ using a stainless steel corer with a diameter of $10 \mathrm{~cm}$. The samples were placed immediately into mesh bags (1.5 mm mesh size) and transferred to plastic bags at the surface. Belowground components were separated into dead material 
and roots + rhizomes, then dried at $60^{\circ} \mathrm{C}$ for $48 \mathrm{~h}$ prior to weighing. As shoot and root/rhizome biomass were collected independently, estimates of above-/belowground biomass ratios were carried out on mean values of these parameters and, as such, no statistical analysis is available.

Morphological measurements were made on the above-ground biomass samples. As the 3 deepest sites had some replicate samples with zero biomass, additional samples were collected at these depths for analysis of these morphological parameters. From each replicate sample, 15 shoots were randomly selected and the number of leaves per shoot recorded. As Posidonia sinuosa shoots usually have only 1 fully mature leaf with or without 1 emergent leaf, all parameters were measured on the mature leaf, including leaf length (from bottom of sheath to leaf tip), leaf width, leaf thickness (using Mitutoyo dial calipers, 505-63350) and epiphyte biomass (dry weighted), quantified by scraping the leaf free of epiphytes using a razor blade and drying at $60^{\circ} \mathrm{C}$ for $48 \mathrm{~h}$. Leaf area index (LAI) was calculated for the mature leaf only by multiplying the leaf length (for the leaf above the sheath only) by the width to obtain area per shoot and then multiplied by shoot density.

Leaf growth: Leaf growth was measured using the leaf hole punch technique (Kirkman \& Reid 1979). At each site, 6 replicate groups of 15 to 20 shoots were hole-punched using a leather punch. On average, 10 to 15 shoots were recovered after 2 to 3 wk of growth. New growth was removed, the length measured, dried

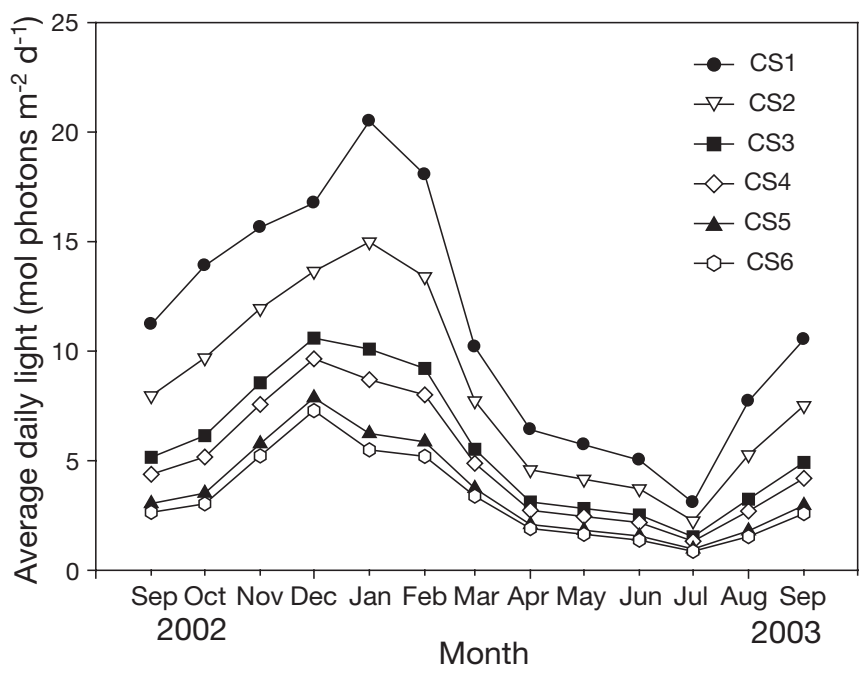

Fig. 2. Average daily light availability (mol photons $\mathrm{m}^{-2} \mathrm{~d}^{-1}$ ) at CS for the period from September 2002 to September 2003 at Sites CS1 to CS6 representing depths of 1.6, 4.0, 5.7, 6.5, 8.3 and $9.0 \mathrm{~m}$, respectively. Data were recorded at $4.0 \mathrm{~m}$ and $9.0 \mathrm{~m}$, and the light extinction co-efficient $(k)$ was used to calculate photosynthetic photon flux density (PPFD) at other depths at $60^{\circ} \mathrm{C}$ for $48 \mathrm{~h}$ and weighed. Shoot turnover time was estimated from the product of the time taken to produce one leaf and the number of leaves per shoot.

Statistical analysis: All data were tested for normality and homogeneity of variances (Levene's median test). If either assumption failed, data were log or square root transformed to achieve the highest Levene's score. If transformation still did not satisfy assumptions of the analysis of variance (ANOVA), the $\mathrm{p}$ value was set to 0.01 to minimise the risk of a Type I error (Underwood 1997). For conforming data, significance was determined at $p<0.05$. Significant effects of season and site (depth) were tested for CS data using a 2-way ANOVA with Site and Season as random factors. Location and site differences were tested using a 2-way ANOVA (Site $\times$ Location) with Site and Location as random factors for all data collected in summer at CS and WS. Tukey's post-hoc analysis was used to further determine differences between the sites sampled, and a $t$-test was used to test for the significance of differences at the same site between seasons or location.

\section{RESULTS}

\section{Environmental parameters}

The mean light attenuation coefficient $(k)$ at CS ranged from $0.12 \mathrm{~m}^{-1}$ in December 2002 to $0.23 \mathrm{~m}^{-1}$ in August 2003. At the more exposed WS location, $k$ was $0.13 \mathrm{~m}^{-1}$ in December 2002 and $0.52 \mathrm{~m}^{-1}$ in July 2003 when storms were prevalent. At the 2 shallowest sites, the daily integrated down-welling PPFD was highest in January (20.5 and 15.0 mol photons $\mathrm{m}^{-2}$ day $^{-1}$ ). At the 4 deeper sites, the daily PPFD was highest in December (10.6, 9.7, 7.9 and $7.3 \mathrm{~mol}$ photons $\mathrm{m}^{-2}$ day $^{-1}$ ) and reached a minimum in July, ranging from 0.6-2.3 mol photons $\mathrm{m}^{-2}$ day $^{-1}$ (Fig. 2). Annual PPFD (calculated from daily PPFD for each month multiplied by the number of days in each month) was 4050,3000 , 2072,1807, 1342 and $1199 \mathrm{~mol}$ photons $\mathrm{m}^{-2} \mathrm{yr}^{-1}$ at the shallowest to deepest sites.

There were no significant differences $(\mathrm{p}>0.05, F=$ 4.02, 0.36 and 1.26 for Sediment Depth, Site and Sediment Depth $\times$ Site, respectively) in redox potential between the depths measured within the sediment cores or between the sites sampled because the variation within a site was very large. The highest redox potential occurred in the surface sediment $(1 \mathrm{~cm})$ at all sites with values ranging from 33.0 to $114.0 \mathrm{mV}$ (SE ranged from 13.8 to 24.0 ). Redox potential at $5-20 \mathrm{~cm}$ sediment depth ranged from 4 to $-184.6 \mathrm{mV}$ (SE at these sediment depths ranged from 38.0 to 141.9 ) with no apparent depth-related pattern. 


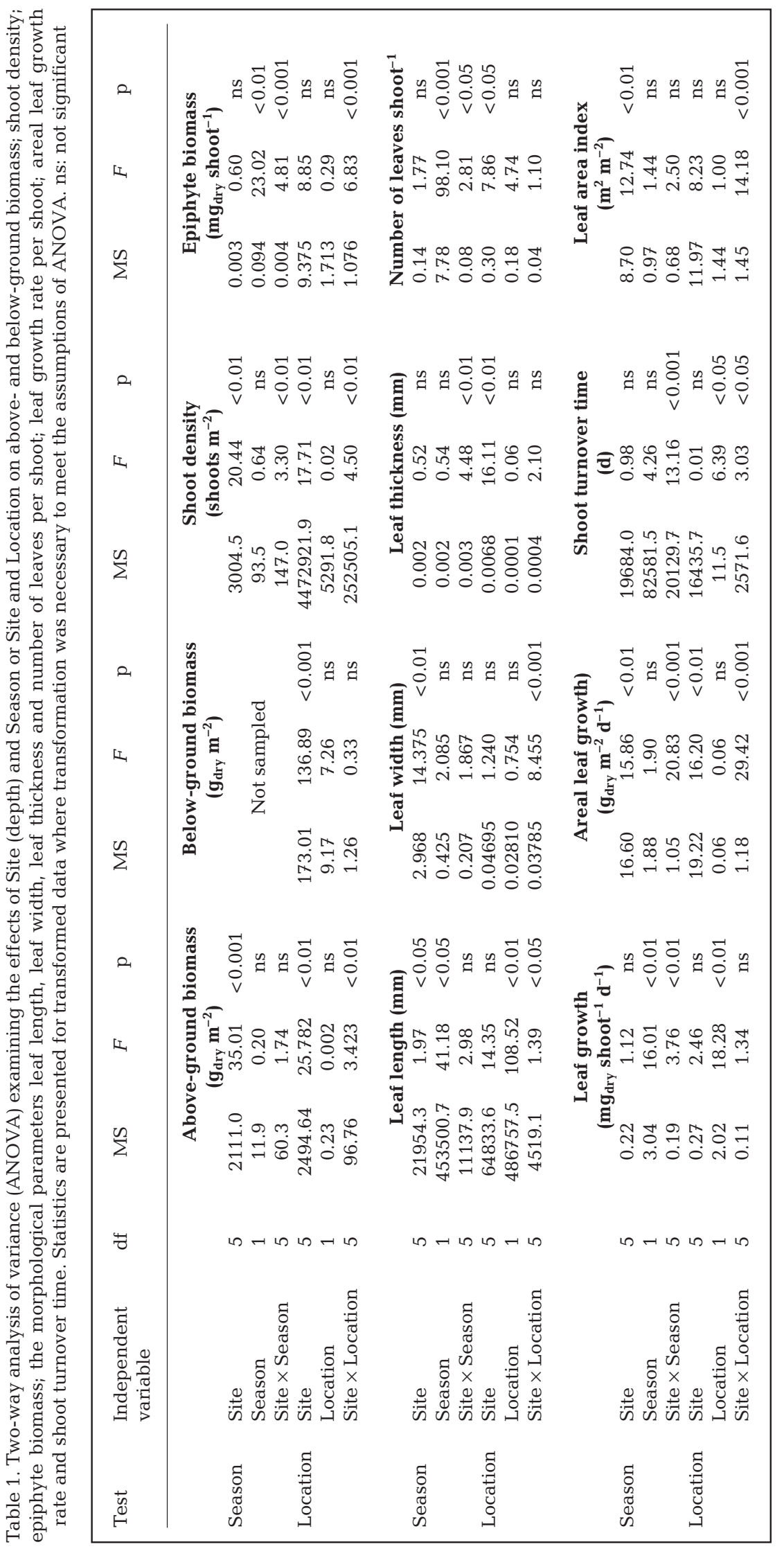

\section{Biomass and morphological parameters}

Above-ground biomass declined significantly ( $p<0.01$; Table 1$)$ with increasing depth at both CS (in summer and winter) and WS (Fig. 3). The differences in above-ground biomass among sites ranged from an 88-fold reduction between the shallowest and deepest sites in CS in winter to a 54- and 40fold reduction in summer at WS and CS, respectively. Shoot density also decreased with depth; however, there were significant Site $\times$ Season and Site $\times$ Location interactions $(\mathrm{p}<0.01)$ : the 2 deepest sites were consistently different from the 2 shallowest sites; differences among the 2 mid-sites (depths 3 and 4) and the deeper (5 and 6 ) and shallower (1 and 2) sites were influenced by season and location. Shoot density reduction ranged from 16- to 61 -fold reduction from the shallowest to deepest site.

Below-ground biomass also demonstrated a significant $(p<0.001$; Table 1$)$ reduction with increased depth at both locations (Fig. 3). Below-ground biomass was highest at the 3 shallowest sites (1, 2 and 3), followed by Site 4, and lowest at the 2 deepest sites. The ratio of above-/below-ground biomass generally increased at deeper sites with the exception of WS4 and WS5. The ratio was $0.6,1.1,0.8,1.9,1.5$ and 2.9 at Sites CS1 to 6 , respectively, while at WS the ratio was $0.5,0.9,1.6,0.7,0.2$ and 1.8 , respectively. This trend in ratio was driven by a greater reduction in belowground than above-ground biomass.

Epiphyte biomass was significantly affected by Site $\times$ Season and Site $\times$ Location interactions $(p<0.001$; Table 1$)$. At both locations, maximum epiphyte biomass occurred at intermediate and deeper sites (CS2, CS3, WS4 and WS6; Fig. 3). At the 4 deeper sites, epiphyte biomass was higher at WS than at CS. At CS, the depth of maximum epiphyte biomass was greater in winter than summer (CS4 in winter compared with CS2 and CS3 in summer), and epiphyte biomass was significantly higher in summer than in winter at all but CS1 and CS4. 
At CS, the number of leaves per shoot was affected by a significant Site $\times$ Season interaction $(p<0.05$; Table 1). In winter, leaf number per shoot was the same at all sites, whereas in summer, it was higher at the 2 deepest sites than at the 2 shallowest sites (Fig. 4). At $\mathrm{CS}, t$-tests indicated that leaf density was significantly higher in summer than in winter at all sites ( $p<0.001)$. When analysed according to location, Posidonia sinuosa shoots had a greater number of leaves per shoot at the 3 deepest sites than at the 3 shallowest sites at both CS and WS.

Leaf width was significantly affected by site ( $p<$ 0.01; Table 1) at CS in summer and winter: it was greatest at the 2 shallowest sites, reduced at the next 2 sites (narrowest at CS4), then increased again at CS5 and CS6 (Fig. 4). A significant ( $p<0.001$; Table 1) Site $\times$ Location interaction for leaf width occurred. At WS, leaf width was narrower than at CS at the 2 shallowest sites; also at WS, width was the greatest at WS2 and narrowest at WS1 and WS6.

At CS, leaf thickness was significantly affected by site at both locations, but the effect was dependent on season (Site $\times$ Season interaction, $\mathrm{p}<0.01$; Table 1 ). In winter, there was no significant effect of site on leaf thickness, but in summer, leaves were thinnest at CS1, and thickest at CS2, CS4, CS5 and CS6. Leaf thickness significantly $(\mathrm{p}<0.001)$ increased in summer only at the deepest site. When analysed according to loca-

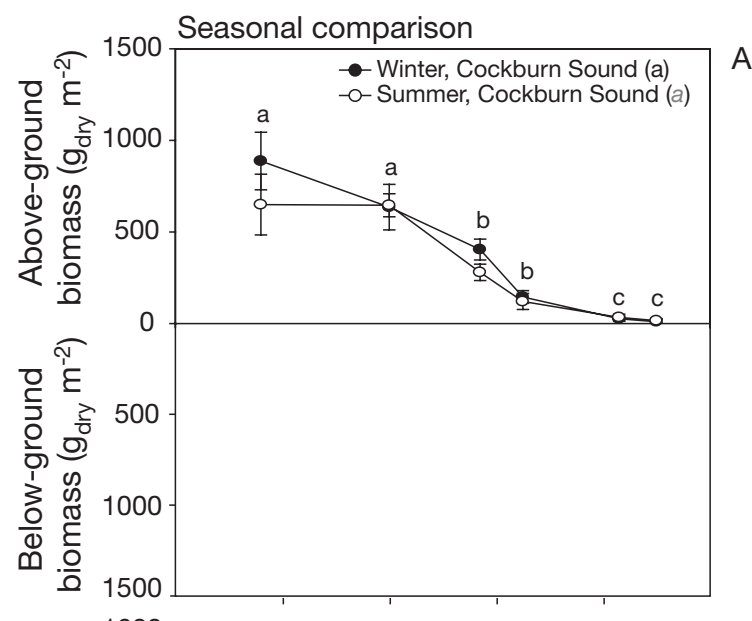

\section{Location comparison}
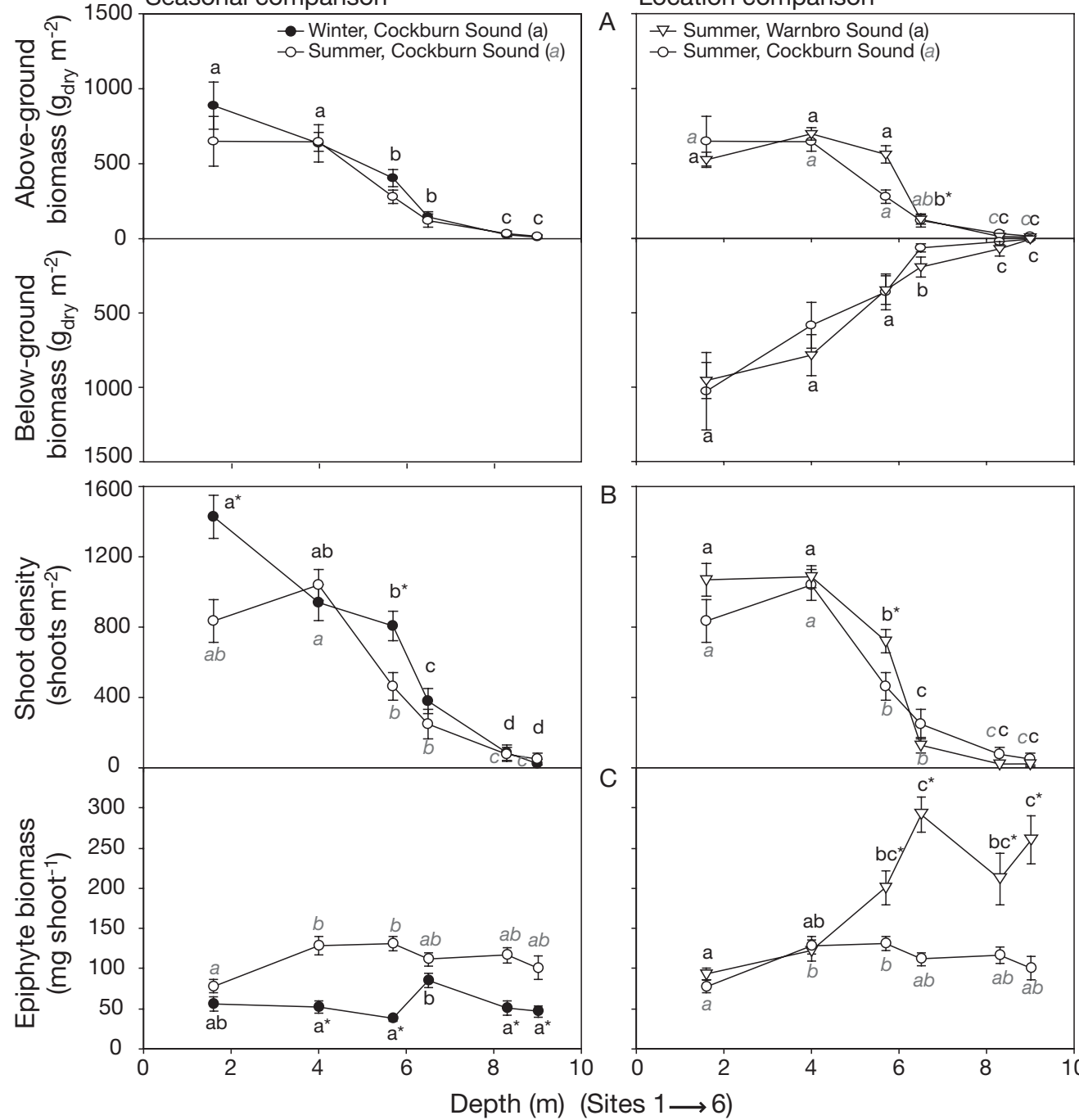

B

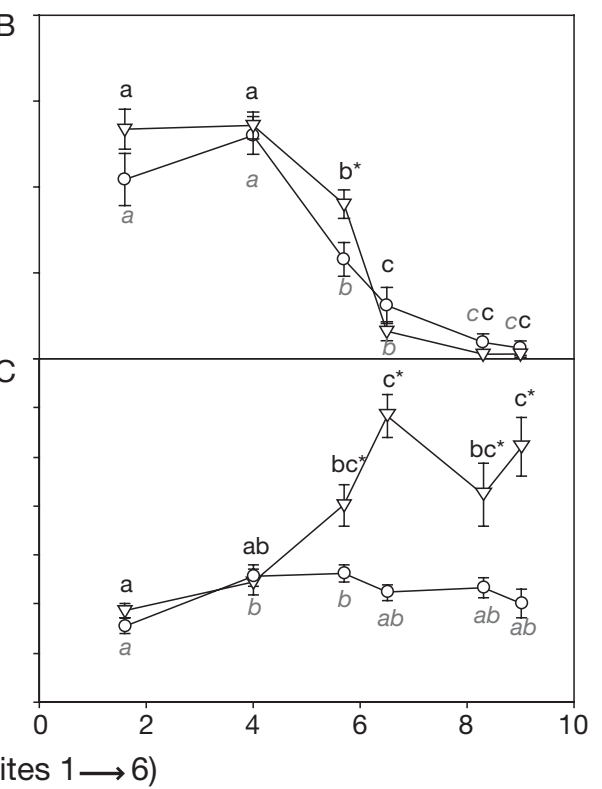

Fig. 3. Posidonia sinuosa biomass at CS in winter 2002 and summer 2003 (left) and at CS and WS in summer 2003 (right) including (A) above-ground biomass (above the axis) and below-ground biomass (summer only; below the axis), (B) shoot density and (C) epiphyte biomass per shoot. Values are means \pm SE $(n=12)$. Depths with the same letters are not significantly different between seasons or locations. Differently shaded letters are independent of each other. ${ }^{*}$ denotes significant differences between summer and winter at CS (left) or differences between locations (right). Data (from left to right) are for Sites CS and WS 1 to 6 in ascending order, corresponding to increasing depth 
tion, leaf thickness increased at deeper sites at both locations.

Leaf length was significantly ( $p<0.05$; Table 1) affected by site at CS, where leaves were longest at the shallowest site and shortest at CS4, increasing again at the 2 deeper sites (Fig. 4). Leaf length was significantly shorter $(\mathrm{p}<0.01)$ at all depths in winter than in summer. Leaf length was also significantly affected by site

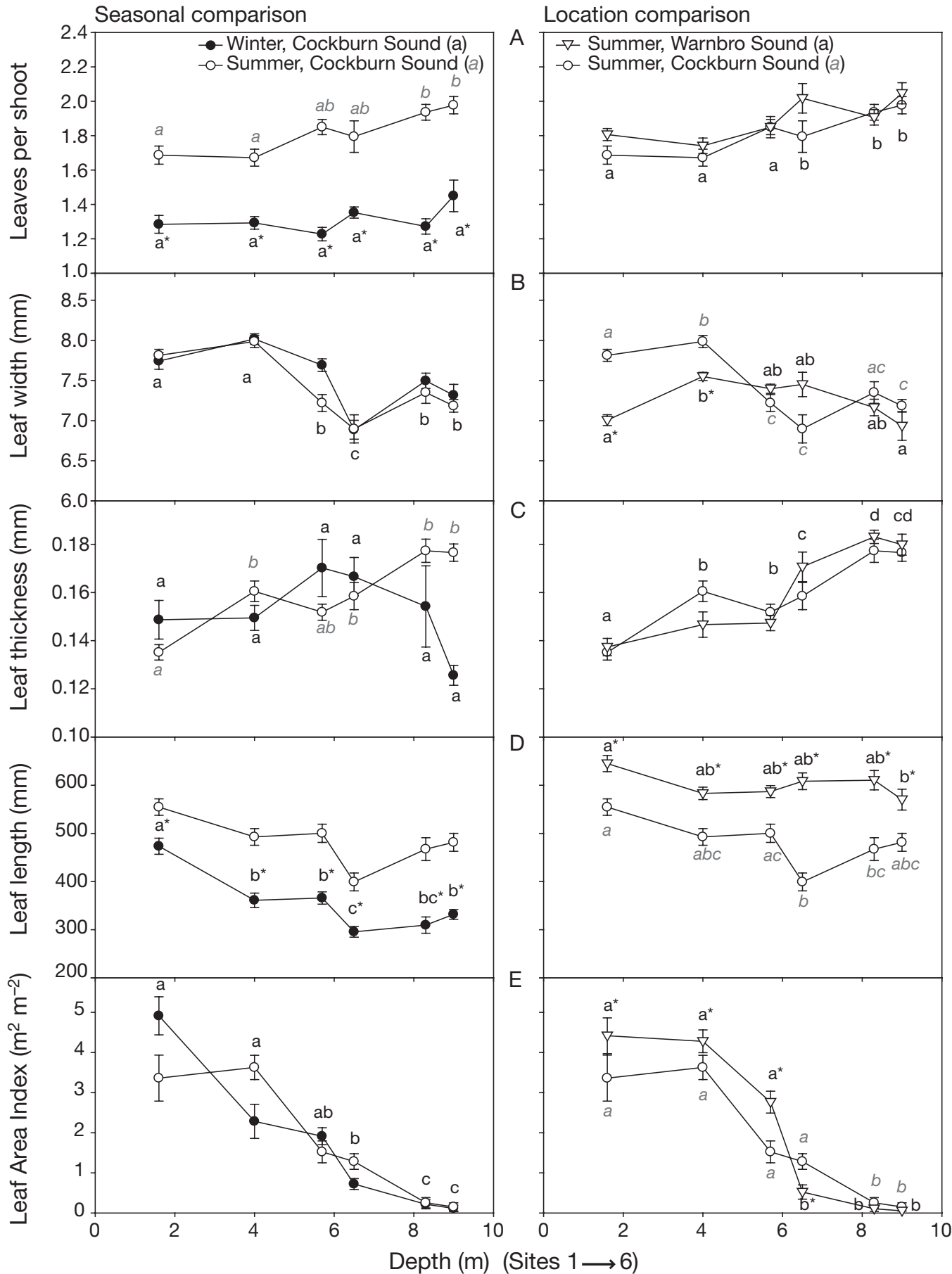

Fig. 4. Posidonia sinuosa morphological characteristics at CS in winter 2002 and summer 2003 (left) and at CS and WS in summer 2003 (right) including (A) number of leaves per shoot, (B) leaf width, (C) thickness, (D) length and (E) leaf area index (LAI) of mature leaves (excluding the young emergent leaf). Values are means $\pm \mathrm{SE}(\mathrm{n}=12$ ). Depths with the same letters are not significantly different within a season or location. Differently shaded letters are independent of each other. ${ }^{*}$ denotes significant differences between summer and winter at CS (left) or differences between location (right). Data (from left to right) are for Sites CS and WS 1 to 6 in ascending order, corresponding to increasing depth 
at WS, but the nature of the site differences was dissimilar to CS (Site $\times$ Location interaction; $\mathrm{p}<0.05$ ). At WS, leaves were longer than at CS. They were longest at WS1 and shortest at WS6.

LAI of the mature leaf was significantly affected by site at CS, with CS1, CS2 and CS3 being significantly higher than CS5 and CS6. Due to a significant Location $\times$ Site interaction $(p<0.001$; Table 1$)$ the depths at which a difference occurred differed between locations; at WS, LAI was significantly lower at the 3 deepest sites compared to the 3 shallowest sites.

In summary, of the characteristics analysed, only biomass, shoot density and LAI demonstrated consistent trends with depth. For the other morphological characteristics, the differences among sites did not strictly follow the depth-related gradient of light availability (e.g. leaf width and length) or the trends varied between the 2 seasons and locations sampled (e.g. leaf thickness and leaves per shoot).

\section{Leaf growth}

In summer, leaf growth per shoot was unaffected by site at both CS and WS (Fig. 5). At CS there was a Site $\times$ Season interaction $(p<0.01$; Table 1$)$ : growth was faster in summer at all but CS1 and CS3, whereas in winter, the shallowest site had the highest rate of growth and CS4 had the lowest rate of growth, while all other sites had intermediate rates.

Areal leaf growth rate reduced significantly at deeper sites; however, the site at which differences occurred depended on location and season (Season $\times$ Site and Location $\times$ Site interactions; $p<0.001$; Table 1). In winter, areal growth rate was fastest at the shallowest site, whereas in summer, it was fastest at the 2 shallowest sites (Fig. 5). In both seasons, growth subsequently declined with depth and was lowest at the 2 deepest sites.

The time taken for the leaves on a shoot to be fully replaced (shoot turnover time in days) was signifi-

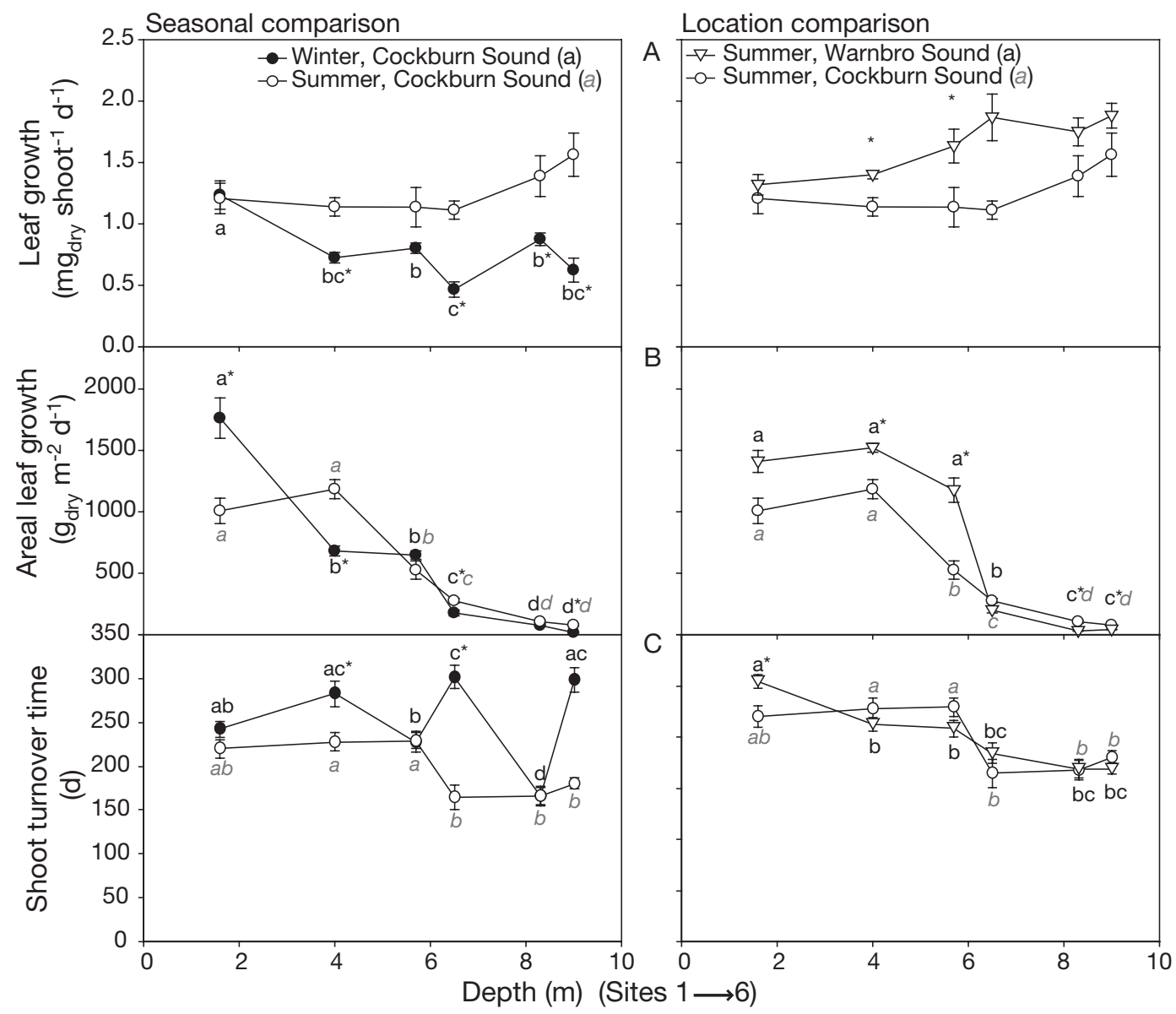

Fig. 5. Posidonia sinuosa leaf growth at CS in winter 2002 and summer 2003 (left) and at CS and WS in summer 2003 (right) including (A) leaf growth rate per shoot, (B) areal leaf growth and (C) shoot turnover time. Values are means \pm SE ( $\mathrm{n}=12$ ). Depths with the same letters are not significantly different between seasons or locations. Differently shaded letters are independent of each other. ${ }^{*}$ denotes significant differences between summer and winter at CS (left) or differences between locations (right). Data (from left to right) are for Sites CS and WS 1 to 6 in ascending order, corresponding to increasing depth 
cantly affected by a Site $\times$ Season $(p<0.001$; Table 1$)$ and Site $\times$ Location $(p<0.05)$ interaction. In summer, shoot turnover time was generally faster at deeper sites than at shallow sites (Fig. 5). This was partially driven by the faster rate of leaf production time at the 3 deeper sites ranging from 83 to $95 \mathrm{~d}$ in summer for both locations (CS and WS), whereas at the 3 shallowest sites, leaf production time was 113 to $140 \mathrm{~d}$. In winter, the slowest rate of shoot turnover was at CS4. Shoot turnover was significantly faster in summer at 3 of the 6 sites and similar between the 2 locations sampled (except at WS1, where turnover was slower).

\section{DISCUSSION}

\section{Posidonia sinuosa light requirements}

Annual light availability at the deepest site in Cockburn Sound (CS) indicates that the minimum light requirement (MLR) for Posidonia sinuosa at this location is about 1200 mol photons $\mathrm{m}^{-2} \mathrm{yr}^{-1}$, approximately $8.5 \%$ of sub-surface irradiance. This is similar to the MLR reported by Masini et al. (1995a), although, if heavily epiphytised, the MLR of $P$. sinuosa may reach as high as $14 \%$ (Masini et al. 1995a) due to the lightattenuating properties of the epiphytes. This places $P$. sinuosa at the lower end of the reported range of MLR (4 to $29 \%$ of sub-surface light; Dennison et al. 1993). Large, persistent species are generally regarded as requiring more light than smaller, transient species as they require more carbon to develop and maintain biomass (Duarte 1991). However, Masini et al. (1995b) found $P$. sinuosa to have lower light requirements than the other south-west Australian meadow-forming species ( $P$. australis and Amphibolis griffithii), and it is often found growing deeper than these species (Sheperd \& Womersley 1981, Kirkman \& Kuo 1990, Cambridge \& Hocking 1997) suggesting that it is a low-light adapted seagrass.

The slow leaf growth rates of Posidonia sinuosa, relative to those reported for other large, persistent meadow-forming seagrasses, may contribute to its lower light requirements. Reported leaf growth values for $P$. oceanica, for example, range from rates of 2-9 mg dry $_{\text {dhoot }}{ }^{-1} \mathrm{~d}^{-1}$ (Bay 1984, Ruiz \& Romero 2001, 2003) and for $P$. australis, 3.5-10 $\mathrm{mg}_{\mathrm{dry}}$ shoot $^{-1} \mathrm{~d}^{-1}$ (Fitzpatrick \& Kirkman 1995). These compare to an average $0.5-1.5 \mathrm{mg}_{\mathrm{dry}}$ shoot $^{-1} \mathrm{~d}^{-1}$ recorded here for $P$. sinuosa, consistent with rates reported by Cambridge and Hocking (1997) for the species. The areal leaf growth rate recorded here for P. sinuosa (1-1.8 $g_{\text {dry }}$ $\mathrm{m}^{-2} \mathrm{~d}^{-1}$ ) is an order of magnitude lower than that expected from a globally derived relationship based on areal growth and above-ground biomass (Duarte \&
Chiscano 1999), i.e. 14-18 $\mathrm{g}_{\mathrm{dry}} \mathrm{m}^{-2} \mathrm{~d}^{-1}$. In addition, $P$. sinuosa has particularly low leaf turnover times of greater than 200 d (Marbà \& Walker 1999) and shoot turnover times that can reach $300 \mathrm{~d}$ in winter. These data indicate that this large meadow-forming species grows slowly, probably investing more of its carbon resources into maintenance of its large biomass, but also that slow growth may be a factor contributing to lower light requirements.

\section{Significance of shoot density adjustments}

A consistent pattern of reduced shoot density, biomass and LAI with increasing depth represents an important adaptation of Posidonia sinuosa to the depth-induced gradient of light availability $(70 \%$ reduction in annual PPFD between the shallowest and deepest sites). Reductions in shoot density with depth are commonly reported for a range of seagrasses and frequently dominate depth gradient characterisations for Posidonia spp. (West 1990, Olesen et al. 2002). It is inferred that such changes represent a response to long-term reductions in light availability. A number of experimental shading studies on seagrasses verify that shoot density reductions do occur in response to light reduction (e.g. Gordon et al. 1994, Ruiz \& Romero 2001), and the consistency with which shoot density declined with the depth-related gradient of light reduction suggests that light is a key environmental factor affecting this characteristic. However, caution is applied here in describing the observed characteristic as a response to light reduction, as the sampling design did not incorporate application of a treatment. Instead, these shoot density differences are considered a characteristic that differs between sites with a number of likely benefits of this to the seagrass.

Only water-column light attenuation was measured in this study; however, light reaching the seagrass leaf can also be attenuated by the canopy and epiphytes on the seagrass leaves (Dalla Via et al. 1998). Light attenuation by dense and tall canopies can be large (Perez \& Romero 1992, Masini et al. 1995b, Dalla Via et al. 1998). Up to $80 \%$ of light in Thalassia testudinum and $85 \%$ in Posidonia australis meadows is attenuated within 5 and $10 \mathrm{~cm}$, respectively, of the canopy surface (Masini \& Manning 1997, Enríquez et al. 2002). Selfshading within dense $P$. sinuosa meadows is probably further enhanced by the bent canopy structure in which the upper half of the long leaves bend over and lie almost horizontally (Smith \& Walker 2002).

Shoot density differences with depth could be considered a meadow-scale response to reduced light availability as the benefits extend to unconnected individuals. Light attenuation by the canopy is reduced 
with decreased LAI, which was controlled by shoot density reductions. This plays a compensatory role in the meadow, and can result in comparable absolute light levels, particularly in the blue and green wavelengths, in the lower region of the canopy for meadows growing at shallow $(3 \mathrm{~m})$ and deep $(10 \mathrm{~m})$ sites (Dalla Via et al. 1998). This response maximises exposure of the lower mid-sections of the leaves, which are frequently the most highly photosynthetic (Ralph et al. 1998, Durako \& Kunzelman 2002) and the most consistently epiphyte-free portion of the seagrass leaves (Dalla Via et al. 1998). These leaf portions are therefore likely to be sensitive to increased light levels in the lower mid-canopy and play a major role in maintaining a positive carbon balance within the meadow. The dominant role of changes in shoot density or LAI have also been reported for other dense meadowforming species including Zostera marina (Dennison 1979) and Posidonia oceanica (Olesen et al. 2002) and its importance in over-riding other responses can be species-specific (Olesen et al. 2002). For species with shorter and sparser canopies, self-shading is probably less important.

Canopy structure optimisation models also consider how the orientation of leaves can influence light absorption and self-shading (Zimmerman 2003, Anten 2005). Bending angles of Thalassia testudinum leaves were an important determinant of total leaf photosynthesis, with bending angles of greater than $20^{\circ}$ creating significant self-shading (Zimmerman 2003). The upper section of Posidonia sinuosa leaves bend over in shallow dense meadows (Smith \& Walker 2002), while at deeper sites, whole leaves lie more horizontal with little overlap due to the low shoot density (C. Collier, pers. obs.). Further analysis of the light absorption properties by the unique canopy structure of $P$. sinuosa and the implications for total photosynthesis are warranted.

Seasonal differences in shoot density were not pronounced, except for the shallow site at CS. The differences recorded at this site are more likely a sampling artifact resulting from the windrow growth formation of Posidonia sinuosa rather than a genuine seasonal fluctuation (C. Collier, pers. obs.). Shoot-density changes with depth were otherwise consistent between seasons. For species investing fewer resources into each shoot, biomass and shoot density can fluctuate considerably over seasonal cycles (Hillman et al. 1995, Sfriso \& Ghetti 1998) as biomass can be easily replaced within a growth cycle. For $P$. sinuosa and other $k$-strategists, however, slow leaf growth and shoot turnover rates prevent a seasonal cycle of shoot production and loss, and shoot density differences between depths reflect longer-term adaptation to the light conditions (West 1990).
Optimisation processes of the canopy involve not only photosynthetic light interception but must also balance respiratory loads. The importance of biomass partitioning for influencing the overall carbon budget of seagrasses has been highlighted by a number of authors (Fourqurean \& Zieman 1991, Masini et al. 1995b, Lee \& Dunton 1997). Although the amount of above-ground material is proportionally small in Posidonia sinuosa (generally between 20 and $40 \%$ ), the respiratory cost of this material can be high. Masini et al. (1995b) found respiratory rates of leaf material to be 4 to 7 times higher than for the root/rhizome complex of $P$. sinuosa. The benefits of reduced shoot density will therefore include reduced shoot respiratory demand. The below-ground material, on the other hand, while beneficial for carbohydrate storage (Pirc 1989, Alcoverro et al. 2001), is energetically costly to maintain due to its proportionally larger biomass $(60-80 \%$ of total biomass). For species in which the ratio of shoot to root/rhizome biomass falls below 2, the below-ground biomass becomes a considerable burden due to a reduced ratio of photosynthesis to respiration (Hemminga 1998). When shaded, the more persistent rhizome can increase as a proportion of total biomass (Lee \& Dunton 1997) and further enhance the respiratory burden. As reported for a number of other species (Kraemer \& Mazzella 1996), the above-/below-ground ratio of $P$. sinuosa biomass was generally less than 1.5 (but reaching 2.9). This ratio generally increased with depth due to reduced below-ground biomass, suggesting that the benefits of the rhizome for carbohydrate storage are outweighed by its respiratory burden.

At deeper sites where the canopy is more open, Posidonia sinuosa rhizomes tended to have more elongated rhizome internodes, which may be an important mechanism to space shoots. Over short timescales, physiological and morphological changes reflecting photoadaptation generally precede shoot loss (Longstaff \& Dennison 1999) prolonging the duration for which the seagrass can survive reduced light. Eventually, however, these responses cannot maintain the meadow and morphological responses result in biomass loss (Neverauskas 1988, Gordon et al. 1994, Ruiz \& Romero 2001). Given the slow growth and turnover of $P$. sinuosa shoots (up to 300 days), shoot production and subsequent loss in response to short-term changes in light availability are energetically inefficient. Unlike the shoot-loss response to shading, canopy thinning along a depth gradient is probably achieved, at least partially, through rhizome elongation. The physical constraints of a dense meadow (as at the shallow sites) cause the rhizomes to develop short internodes with closely spaced shoots (Cambridge 1999), while more rapid rhizome elongation can occur where densitydependant constraints are removed (Marbà \& Duarte 
1998). As a range of triggers for increased rhizome extension are possible, e.g. burial (Marbà \& Duarte 1995), further investigation on the importance for spacing shoots at deeper sites where light is limiting is warranted.

\section{Variation in morphology and growth}

At both sites, morphological differences between depths were small and generally limited to the shallowest 1 or 2 depths, suggesting they do not play a major role in the depth-acclimation of Posidonia sinuosa near its depth limit. Detailed investigations into the physiological characteristics of $P$. sinuosa along a depth-related gradient of light availability also indicate that photosynthetic characteristics including photosynthetic and photoprotective pigments and electron transport rates also do not follow the light gradient (Collier 2006). Despite a 2-fold difference in PPFD between the $4 \mathrm{~m}$ (CS2) and $9 \mathrm{~m}$ (CS6) sites, no clear or consistent differences in the morphological characteristics were observed. In response to intense shading, distinct reductions in leaf length (to less than $10 \mathrm{~cm}$ final length) preceding shoot loss have been observed in P. sinuosa (Gordon et al. 1994). Under the more stable long-term light conditions occurring here, the differences were much smaller. The small morphological changes that do occur contribute to a reduced LAI and probably result in a thinner canopy.

An alternate and opposing response to reduced light includes increases in leaf width in Posidonia oceanica (Dalla Via et al. 1998) or leaf length in Heterozostera tasmanica (Bulthius 1983) and Halophila ovalis (Hillman et al. 1995), which are considered to be mechanisms that increase light capture (Dalla Via et al. 1998). However, leaf width reductions with depth have been reported for P. sinuosa (Masini \& Manning 1994) and Thalassia testudinum (Lee \& Dunton 1997). As was suggested for T. testudinum, a reduction of leaf width may contribute to canopy thinning. In contrast, leaf thickness here increased slightly with depth at both sites in summer, a feature that could increase light absorption due to a higher density of refractive structures such as air bubbles or intracellular crystals, although these benefits require further investigation (Enríquez 2005).

The influence of external factors, such as sediment type, on these morphological characteristics is likely to have been minimised in this study due to the close proximity of the sampling sites (except for the shallowest site). Other factors may have some influence, such as hydrodynamics and sediment redox potential. The hydrodynamic forces of swell waves, for example, may shape these characteristics, particularly at the shallow- est site. It has been proposed that leaf length in Posidonia australis may be reduced by the hydrodynamic forces of swell and wind-driven waves (West 1990). As the shallower sites would be more impacted by swell, this effect may tend to counteract any reductions in leaf length due to depth-related light attenuation. The more stable conditions prevailing at depth may also slow leaf senescence and enable the number of leaves per shoot to increase with depth during summer. As there does not appear to be a depth-related effect on sediment redox at $\mathrm{CS}$, it is unlikely that the reducing conditions of the generally well-mixed sediments are responsible for any of the morphological variability. Other sediment-related factors such as nutrients in the sediment porewater were not investigated, but may be a limiting factor for the dense, shallow meadow, particularly during summer, and may mask the influence of the light gradient.

The hypothesis that leaf growth declines with reduced light availability, as is frequently reported (Gordon et al. 1994, Lee \& Dunton 1997), did not hold for the depth-related gradient of light availability at either CS or WS in summer. The comparable leaf growth rates among depths would suggest that light availability at the leaf surface, due in part to reduced shoot density, is sufficient to meet growth demands during summer. Physiological changes may enhance light harvesting and conversion into fixed carbon where light availability is reduced (Dennison \& Alberte 1982, Abal et al. 1994); however, related studies have shown that these were not important depth response mechanisms in Posidonia sinuosa (Collier 2006). Instead, we propose that reduced shoot density partially alleviated the effects of self-shading, compensating for the gradient of light availability at the top of the canopy and enabling comparable growth between depths. However, even when light is reduced at the leaf surface, leaf growth rate may not be affected (Kraemer \& Hanisak 2000) or can even increase (Abal et al. 1994). That growth was similar at all sites during summer may also reflect the importance of light saturated hours of photosynthesis $\left(\mathrm{H}_{\mathrm{sat}}\right)$ for determining seagrass responses to light availability, where, above a certain threshold, further increases in $\mathrm{H}_{\text {sat }}$ do not correlate with increased leaf formation rates (Dennison \& Alberte 1985). In winter, when the magnitude of differences in light availability was also greater, growth differed between the shallowest and all other sites.

Reduced leaf growth and leaf turnover with increasing depth can contribute to epiphyte accumulation in the lower energy (Tomasko \& Dawes 1990, Cambridge \& Hocking 1997), deeper sites where the abrasive effects of canopy movement are small. The winter leaf turnover rate was slowest at CS4, the site that had almost double the shoot epiphyte load of other sites. 
However, the other sites also had slow turnover rates without the dramatically higher epiphyte loads, suggesting turnover rate alone does not explain epiphyte biomass. The light-attenuating effects of this epiphyte accumulation (Burt et al. 1995, Brush \& Nixon 2002) may contribute to the morphological anomalies at this particular depth at CS.

In conclusion, shoot density, biomass and LAI were characteristics that responded strongly and consistently down the depth-related gradient of light availability. Although it is reported for many species, the importance of reduced shoot density for minimising the effects of self-shading is likely to have the most dramatic impact on those species that form large, dense canopies. Moreover, Posidonia sinuosa has comparably slow growth and shoot replacement rates placing further importance on a mechanism to cope with low light availability that is beneficial over the longterm. Other morphological and growth responses, where present, were less pronounced. While we can speculate over the reasons for seasonal, location- and site-related variability, ultimately the depth-related gradient of light availability did not have a dominant effect on those other morphological characteristics that are frequently proposed as monitoring indicators.

Acknowledgements. We thank all of those who assisted with the field collection of samples, in particular P. Mackey, J. How, J. Hooper and T. Daly. Thanks also to the Strategic Research Fund for the Marine Environment and the Centre for Ecosystem Management for funding.

\section{LITERATURE CITED}

Abal EG, Dennison WC (1996) Seagrass depth range and water quality in southern Moreton Bay, Queensland, Australia. Mar Freshw Res 47:763-771

Abal EG, Loneragan NR, Bowen P, Perry CJ, Udy JW, Dennison WC (1994) Physiological and morphological responses of the seagrass Zostera capricorni Aschers. to light intensity. J Exp Mar Biol Ecol 178:113-129

Alcoverro T, Manzanera M, Romero J (2001) Annual metabolic carbon balance of the seagrass Posidonia oceanica: the importance of carbon reserves. Mar Ecol Prog Ser 211: 105-116

Anten NPR (2005) Optimal photosynthetic characteristics of individual plants in vegetation stands and implications for species coexistence. Ann Bot 95:495-506

Bay D (1984) A field study of the growth dynamics and productivity of Posidonia oceanica (L.) Delile in Calvi Bay, Corsica. Aquat Bot 20:43-64

Brush MJ, Nixon SW (2002) Direct measurement of light attenuation by epiphytes on eelgrass Zostera marina. Mar Ecol Prog Ser 238:73-79

Bulthius DA (1983) Effects of in situ light reduction on density and growth of the seagrass Heterozostera tasmanica (Martens ex Aschers.) den Hartog in Western Port, Victoria, Australia. J Exp Mar Biol Ecol 67:91-103

Burt JS, Kendrick GA, Masini RJ, Simpson CJ (1995) Light and Posidonia sinuosa seagrass meadows in the temperate coastal waters of Western Australia II. Effect of epiphyte species assemblages and biomass on attenuating light to the leaf surface. Tech Ser 61, Department of Environmental Protection, Perth, Western Australia

Cambridge ML (1999) Growth strategies of Rottnest Island seagrasses. In: Walker DI, Wells FE (eds) The seagrass flora and fauna of Rottnest Island, Western Australia. Western Australia Museum, Perth, p 1-24

Cambridge ML, Hocking PJ (1997) Annual primary production and nutrient dynamics of the seagrasses Posidonia sinuosa and Posidonia australis in south-western Australia. Aquat Bot 59:277-295

Carruthers TJB, Longstaff BJ, Dennison WC, Abal EG, Aioi K (2001) Measurement of light penetration in relation to seagrass. In: Short FTT, Coles R (eds) Global Seagrass Research Methods. Elsevier, Amsterdam, p 369-392

Collier CJ (2006) Characterisation of the seagrass, Posidonia sinuosa, responses to light availability. PhD dissertation, Edith Cowan University, Perth

Counihan R, Costanzo S, D'Souza F, Dennison WC and 10 others (2002) Ecosystem Health Monitoring Program 2001-2002 annual report. CRC Coastal Zone, Estuary and Waterway Management and the Moreton Bay Waterways and Catchments Partnership, Brisbane

Czerny AB, Dunton KH (1995) The effects of in situ light reduction on the growth of two subtropical seagrasses, Thalassia testudinum and Halodule wrightii. Estuaries 18: 418-427

Dalla Via J, Sturmbauer C, Schönweger G, Sötz E, Mathekowitsch S, Stifter M, Rieger R (1998) Light gradients and meadow structure in Posidonia oceanica: ecomorphological and functional correlates. Mar Ecol Prog Ser 163:267-278

Dennison WC (1979) Light adaptations of plants: a model based on the seagrass Zostera marina L. MS thesis, University of Alaska, Fairbanks

Dennison WC (1987) Effects of light on seagrass photosynthesis, growth and depth distribution. Aquat Bot 27:15-26

Dennison WC, Alberte RS (1982) Photosynthetic responses of Zostera marina L. (eelgrass) to in situ manipulations of light intensity. Oecologia 55:137-144

Dennison WC, Alberte RS (1985) Role of daily light period in the depth distribution of Zostera marina (eelgrass). Mar Ecol Prog Ser 25:51-61

Dennison WC, Orth RJ, Moore KA, Stevenson C, Carter V, Kollar S, Bergstrom PW, Batiuk RA (1993) Assessing water quality with submersed aquatic vegetation: habitat requirements as barometers of Chesapeake Bay health. BioScience 43:86-94

Duarte CM (1991) Seagrass depth limits. Aquat Bot 40: 363-377

Duarte CM, Chiscano CL (1999) Seagrass biomass and production: a reassessment. Aquat Bot 65:159-174

Durako MJ, Kunzelman JI (2002) Photosynthetic characteristics of Thalassia testudinum measured in situ by pulseamplitude modulated (PAM) fluorometry: methodological and scale-based considerations. Aquat Bot 73:173-185

Enríquez S (2005) Light absorption efficiency and the package effect in the leaves of the seagrass Thalassia testudinum. Mar Ecol Prog Ser 289:141-150

Enríquez S, Merino M, Iglesias-Prieto R (2002) Variations in the photosynthetic performance along the leaves of the tropical seagrass Thalassia testudinum. Mar Biol 140: 891-900

Fitzpatrick J, Kirkman H (1995) Effects of prolonged shading stress on growth and survival of seagrass Posidonia australis in Jervis Bay, New South Wales, Australia. Mar Ecol Prog Ser 127:279-289 
Fourqurean JW, Zieman JC (1991) Photosynthesis, respiration and whole plant carbon budget of the seagrass Thalassia testudinum. Mar Ecol Prog Ser 69:161-170

Gordon DM, Grey KA, Chase SC, Simpson CJ (1994) Changes to the structure and productivity of a Posidonia sinuosa meadow during and after imposed shading. Aquat Bot 47:265-275

Hemminga MA (1998) The root/rhizome system of seagrasses: an asset and a burden. J Sea Res 39:183-196

Hillman K, McComb AJ, Walker DI (1995) The distribution, biomass and primary production of the seagrass Halophila ovalis in the Swan/Canning Estuary, Western Australia. Aquat Bot 51:1-54

Kenworthy WJ, Fonesca MS (1996) Light requirements of seagrasses Halodule wrightii and Syringodium filiforme derived from the relationship between diffuse light attenuation and maximum depth distribution. Estuaries 19: $740-750$

Kirk JTO (1994) Light and photosynthesis in aquatic ecosystems, 2nd edn. Cambridge University Press, Cambridge

Kirkman H, Kuo J (1990) Pattern and process in southern Western Australian seagrasses. Aquat Bot 37:367-382

Kirkman H, Reid DD (1979) A study of the role of the seagrass Posidonia australis in the carbon budget of an estuary. Aquat Bot 7:173-183

Kraemer GP, Hanisak MD (2000) Physiological and growth responses of Thalassia testudinum to environmentalrelevant periods of low irradiance. Aquat Bot 67: 287-300

Kraemer GP, Mazzella L (1996) Nitrogen assimilation and growth dynamics of the Mediterranean seagrasses Posidonia oceanica, Cymodocea nodosa, and Zostera noltii. In: Kuo J, Phillips RC, Walker DI, Kirkman H (eds) Seagrass biology: Proceedings of an international workshop. Western Australian Museum, Rottnest Island, Western Australia, p 181-190

Lavery P, Westera M (2005) A survey of selected seagrass meadows in the Fremantle-Warnbro Sound region 2005. Report No. 2005-02, Edith Cowan University, Perth

Lee KS, Dunton KH (1997) Effects of in-situ light reduction on the maintenance, growth, and partitioning of carbon resources in Thalassia testudinum Banks ex Konig. J Exp Mar Biol Ecol 210:53-73

Longstaff BJ (2000) Investigations into the light requirements of seagrasses in northeast Australia. PhD dissertation, University of Queensland, Brisbane

Longstaff BJ, Dennison WC (1999) Seagrass survival during pulsed turbidity events: the effects of light deprivation on the seagrasses Halodule pinifolia and Halophila ovalis. Aquat Bot 65:101-121

Marbà N, Duarte CM (1995) Coupling of seagrass (Cymodocea nodosa) patch dynamics to subaqueous dune migration. J Ecol 83:381-389

Marbà N, Duarte CM (1998) Rhizome elongation and seagrass clonal growth. Mar Ecol Prog Ser 174:269-280

Marbà N, Walker DI (1999) Growth, flowering and population dynamics of temperate Western Australian seagrasses. Mar Ecol Prog Ser 184:105-118

Masini RJ, Manning CR (1994) Seagrasses, epiphytes and macroalgae: critical irradiances and metabolic rates. Data Report SMCWS ECOL-2, Department of Environmental Protection, Perth, Western Australia

Editorial responsibility: Otto Kinne (Editor-in-Chief), Oldendorf/Luhe, Germany
Masini RJ, Manning CR (1997) The photosynthetic responses to irradiance and temperature of four meadow-forming seagrasses. Aquat Bot 58:21-36

Masini RJ, Burt JS, Simpson CJ (1995a) Light and Posidonia seagrass meadows in the temperate coastal waters of Western Australia. III Minimum light requirements. Tech Ser 65, Department of Environmental Protection, Perth, Western Australia

Masini RJ, Cary JL, Simpson CJ, McComb AJ (1995b) Effects of light and temperature on the photosynthesis of temperate meadow-forming seagrasses in Western Australia. Aquat Bot 49:239-254

Neverauskas VP (1988) Response of a Posidonia community to prolonged reduction in light. Aquat Bot 31:361-366

Olesen B, Enríquez S, Duarte CM, Sand-Jensen K (2002) Depth-acclimation of photosynthesis, morphology and demography of Posidonia oceanica and Cymodocea nodosa in the Spanish Mediterranean Sea. Mar Ecol Prog Ser 236:89-97

Peralta G, Perez-Llorens JL, Hernandez I, Vergara JJ (2002) Effects of light availability on growth, architecture and nutrient content of the seagrass Zostera noltii Hornem. J Exp Mar Biol Ecol 269:9-26

Perez M, Romero J (1992) Photosynthetic response to light and temperature of the seagrass Cymodocea nodosa and the prediction of its seasonality. Aquat Bot 43:51-62

Pirc H (1989) Seasonal changes in soluble carbohydrates, starch, and energy content in Mediterranean seagrasses. PSZN I: Mar Ecol 10:97-105

Ralph PJ, Gademann R (2005) Rapid light curves: a powerful tool to assess photosynthetic activity. Aquat Bot 82:222-237

Ralph PJ, Gademann R, Dennison WC (1998) In situ seagrass photosynthesis measured using a submersible, pulseamplitude modulated fluorometer. Mar Biol 132:367-373

Ruiz JM, Romero J (2001) Effects of in situ experimental shading on the Mediterranean seagrass Posidonia oceanica. Mar Ecol Prog Ser 215:107-120

Ruiz JM, Romero J (2003) Effects of disturbances caused by coastal constructions on spatial structure, growth dynamics and photosynthesis of the seagrass Posidonia oceanica. Mar Poll Bull 46:1523-1533

Sfriso A, Ghetti PF (1998) Seasonal variation in biomass, morphometric parameters and production of seagrasses in the lagoon of Venice. Aquat Bot 61:207-223

Sheperd SA, Womersley HBS (1981) The algal and seagrass ecology of Waterloo Bay, South Australia. Aquat Bot 11: 305-371

Smith NM, Walker DI (2002) Canopy structure and pollination biology of the seagrasses Posidonia australis and $P$. sinuosa (Posidoniaceae). Aquat Bot 74:57-70

Tomasko DA, Dawes CJ (1990) Influences of season and water depth on the clonal biology of the seagrass Thalassia testudinum. Mar Biol 105:345-351

Underwood AJ (1997) Experiments in ecology: their logical design and interpretation using analysis of variance. Cambridge University Press, Cambridge

West RJ (1990) Depth-related structural and morphological variations in an Australian Posidonia seagrass bed. Aquat Bot 36:153-166

Zimmerman RC (2003) A biooptical model of irradiance distribution and photosynthesis in seagrass canopies. Limnol Oceanogr 48:568-585

Submitted: March 10, 2006; Accepted: September 1, 2006 Proofs received from author(s): April 17, 2007 